\title{
Prognosis for Infants with Idiopathic Respiratory Distress Syndrome
}

\author{
N. R. C. ROBERTON, J. P. M. TIZARD
}

British Medical fournal, 1975, 3, 271-274

\begin{abstract}
Summary
Infants with the idiopathic respiratory distress syndrome admitted to the intensive care unit during January 1972 to September 1974 were reviewed. The overall mortality rate for infants whose birth weight was $1000 \mathrm{~g}$ or more was under $10 \%$, and for those who established spontaneous respiration after birth it was less than $5 \%$. The hyperoxia test was not a useful guide to prognosis. It was possible on the basis of the infants' ability to establish spontaneous ventilation after birth to divide them into two groups. In those who established adequate ventilation the mortality rate was $4.5 \%$; in those who did not it was $57 \%$. This test should be generally applied, since not only does it give an immediate guide to the severity of the disease, which is better than that provided by birth weight, gestational age, or the hyperoxia test, but it may be applied to infants born in and outside a hospital providing neonatal intensive care.

Improvement in the outlook for infants with a bad prognosis will be achieved only by improvements in perinatal care designed to minimize severe intrapartum asphyxia in infants of low birth weight.
\end{abstract}

\section{Introduction}

Most neonatologists agree on the criteria for the diagnosis of the idiopathic respiratory distress syndrome (I.R.D.S.) due to surfactant deficiency and associated with the finding of hyaline membrane disease (H.M.D.) at necropsy. ${ }^{1}$ New methods of treatment, however, are difficult to evaluate by comparing results from different neonatal intensive care units. There are three reasons for this. Firstly, units vary in the proportions of babies with I.R.D.S. born in and outside the hospital. The prognosis for the latter is bound to be different. Those worst affected may die before transfer, whereas the outcome in those reaching the intensive care unit will depend on the quality of perinatal care they have received and the hazards of the journey. Secondly, the proportion of babies of very low birth weight admitted to different units varies, and since such infants have a high mortality it seems reasonable to consider separately those with a birth weight under $1000 \mathrm{~g}$. The third difficulty is in the provision of an objective assessment of the severity of I.R.D.S.

Boston et al. ${ }^{2}$ showed that infants under 10 hours old whose arterial oxygen pressure $\left(\mathrm{PaO}_{2}\right)$ was less than $13.3 \mathrm{kPa}(100 \mathrm{~mm}$ $\mathrm{Hg})$ in a fractional inspired oxygen $\left(\mathrm{F}_{1} \mathrm{O}_{2}\right)$ of 1.0 had a mortality of $81 \%$, whereas those whose $\mathrm{PaO}_{2}$ was greater than $13.3 \mathrm{kPa}$ had a mortality of $29 \%$. We confirmed the prognostic value of this hyperoxia test ${ }^{3}$ and found an overall mortality from I.R.D.S. of $30 \%$ in infants of over 28 weeks of gestation. Since then, however, the mortality rate has fallen with advances in

University Department of Paediatrics, John Radcliffe Hospital, Oxford OX3 9DU

N. R. C. ROBERTON, M.B., M.R.C.P., Lecturer (Present address: Addenbrooke's Hospital, Cambridge)

J. P. M. TIZARD, F.R.C.P., D.C.H., Professor management such as careful blood gas monitoring, ${ }^{3}$ the use of continuous distending pressure (C.D.P.) $)^{4-7}$ the maintenance of blood volume, ${ }^{8}$ and improvements in intermittent positivepressure ventilation (I.P.P.V.). ${ }^{9}$

All cases of I.R.D.S. admitted to the intensive care unit of the United Oxford Hospitals between 1 January 1972 and 30 September 1974 were therefore reviewed $(a)$ to establish the mortality rate for I.R.D.S. in infants needing and not needing I.P.P.V.; $(b)$ to assess the prognostic value of the hyperoxia test in these infants; and $(c)$ to see whether other information readily available in the first few hours of life has any prognostic value.

\section{Patients and Methods}

All babies admitted to the intensive care unit with I.R.D.S. were studied. The diagnosis was made in the presence of any two of the following three symptoms persisting for at least one hour and developing before 4 hours of age: tachypnoea greater than $60 / \mathrm{min}$; subcostal or intercostal retraction; expiratory grunt. I.R.D.S. was also diagnosed when I.P.P.V. was required before 4 hours of age and H.M.D. seemed likely clinically and radiologically. Other causes of respiratory distress in the first four hours of life were excluded radiologically.

In 146 infants hyperoxia tests were carried out as soon as umbilical catheters were inserted. The test was performed within 12 hours of birth, and usually much earlier (table I). Seventy-five infants did not have hyperoxia tests carried out-(a) 12 infants thought at first to be too mildly affected to warrant arterial catheterization but who subsequently deteriorated and had umbilical catheters inserted after 12 hours; (b) four infants in whom an arterial catheter could not be passed; (c) 32 infants with mild disease who were managed with the use of peripheral arterial samples; and $(d) 27$ infants on assisted ventilation from birth (6 C.D.P.; 21 I.P.P.V.).

TABLE I-Age of Infants when Hyperoxia Tests were Carried Out

\begin{tabular}{l|r|r|r|r|r|r|r|r|r|r|r|r|r}
\hline Age (hours): & 1 & 2 & 3 & 4 & 5 & 6 & 7 & 8 & 9 & 10 & 11 & 12 & Total \\
\hline $\begin{array}{l}\text { No. tested } \\
\text { No. of deaths }\end{array}$ & 10 & $\begin{array}{r}42 \\
1\end{array}$ & 33 & 15 & 16 & 9 & 7 & 6 & 4 & 1 & 1 & 2 & 146 \\
\hline
\end{tabular}

TABLE II-Grouping of Infants on whom Hyperoxia Tests were Carried Out

\begin{tabular}{|c|c|c|c|c|}
\hline \multirow{2}{*}{ Group } & \multicolumn{2}{|c|}{$\mathrm{A}-\mathrm{aDo} \mathrm{O}_{2}$} & \multicolumn{2}{|c|}{$\begin{array}{l}\text { Approximate Equivalent } \\
\mathrm{PaO}_{2} \text { in } 100 \% \mathrm{O}_{2}\end{array}$} \\
\hline & $\mathrm{kPa}$ & $\mathrm{mm} \mathrm{Hg}$ & $\mathbf{k P a}$ & $\mathrm{mm} \mathrm{Hg}$ \\
\hline $\begin{array}{l}1 \\
2 \\
3 \\
4 \\
5\end{array}$ & $\begin{array}{c}\geqslant 76 \cdot 4 \\
69 \cdot 8-76 \cdot 3 \\
63 \cdot 1-69 \cdot 7 \\
56 \cdot 5-63 \cdot 0 \\
<56.5\end{array}$ & $\begin{array}{l}\geqslant 575 \\
525-574 \\
475-524 \\
425-474 \\
<425\end{array}$ & $\begin{array}{c}\leqslant 13 \cdot 3 \\
13 \cdot 3-19 \cdot 8 \\
19 \cdot 9-26 \cdot 5 \\
26 \cdot 6-33 \cdot 1 \\
>33 \cdot 2\end{array}$ & $\begin{array}{c}\leqslant 100 \\
100-149 \\
150-199 \\
200-249 \\
>250\end{array}$ \\
\hline
\end{tabular}

The hyperoxia test was carried out by giving 70-100\% oxygen for 15 minutes. To compare the results at different $\mathrm{F}_{1} \mathrm{O}_{2}$ levels the alveolararterial oxygen tension difference $\left(\mathrm{A}-\mathrm{aDO}_{2}\right)$ was calculated from the known $\mathrm{F}_{1} \mathrm{O}_{2}, \mathrm{PaO}_{2}$, and $\mathrm{PaCO}_{2}$, a respiratory quotient (R.Q.) of 0.8 being assumed. The infants were divided into five groups according to their $\mathrm{A}-\mathrm{aDO}_{2}$ (table II). A lower limit of less than $56.5 \mathrm{kPa}(425 \mathrm{~mm} \mathrm{Hg})$ was used because it corresponds to a $\mathrm{PaO}_{2}$ of about $33.2 \mathrm{kPa}(250$ $\mathrm{mm} \mathrm{Hg}$ ) and the blood gas analyser used could not register a $\mathrm{PaO}_{2}$ of over $37 \cdot 2 \mathrm{kPa}(280 \mathrm{~mm} \mathrm{Hg})$.

The management of these infants is detailed elsewhere. ${ }^{8}$ As soon as I.R.D.S. was diagnosed umbilical catheters were inserted. The arterial catheter was used to sample for blood gas analysis and also for 
continuous blood pressure monitoring. Oxygen was administered to keep the $\mathrm{PaO}_{2}$ of lower abdominal aorta blood at 8-12 kPa (60-90 $\mathrm{mm} \mathrm{Hg}$ ); the $\mathrm{pH}$ was maintained greater than $7 \cdot 25$ by single infusions of sodium bicarbonate: trometamol was used only rarely. $\mathrm{A} \mathrm{PaO}_{2}$ under $8 \mathrm{kPa}$ in a $\mathrm{F}_{1} \mathrm{O}_{2}$ of 0.6 was an indication for C.D.P. to be given by a headbox, endotracheal tube, nasal prongs, or negative pressure chamber at different times during the period. I.P.P.V. was given either by a Bennett PR2 Special ventilator or by the Draeger Spiromat 660. The indications for I.P.P.V. are shown in table III. Blood pressure and packed cell volume were maintained within normal limits by frequent small transfusions of fresh heparinized blood. ${ }^{8}$ Plasma sodium, potassium, and calcium were measured daily. Feeding with pooled expressed breast milk was given when tolerated. When pooling of feeds occurred in the stomach short-term hydration was maintained with intravenous $5-10 \%$ dextrose with electrolyte supplements. Intravenous feeding was used for only six infants.

TABLE III-Indications for I.P.P.V.

\begin{tabular}{|c|c|c|c|}
\hline & \multirow{2}{*}{$\begin{array}{c}\text { No. } \\
\text { Ventilated }\end{array}$} & \multicolumn{2}{|c|}{ Died } \\
\hline & & No. & $\%$ \\
\hline $\begin{array}{l}\text { Failure to establish adequate ventilation } \\
15 \text { min after birth, necessitating } \\
\text { long-term I.P.P.V. } \\
\text { Deteriorating blood gas levels in infants } \\
\text { breathing regularly } \\
\text { Development of persistent apnoea or irregular } \\
\text { gasping respirations in infants previously } \\
\text { breathing regularly: } \\
\text { (a) While breathing unassisted } \\
\text { (b) During setting up of C.D.P. } \\
\text { (c) While receiving C.D.P. }\end{array}$ & $\left.\begin{array}{r}10 \\
4 \\
9^{*}\end{array}\right\} 23$ & $\left.\begin{array}{l}3 \\
1 \\
4\end{array}\right\} 8$ & $57 \cdot 1$ \\
\hline Total & 48 & 20 & $41 \cdot 7$ \\
\hline
\end{tabular}

-Of these nine cases, three (all deaths) were due to apnoea after development of pneumothorax; four (one death) were due to persistent apnoea; and two were due to apnoea caused by obstruction of endotracheal tube used to administer C.D.P.

\section{Results}

During the period of study 11913 infants weighing over $1000 \mathrm{~g}$ were born in the John Radcliffe Hospital. Seventy-five died in the first seven days of life, an early neonatal mortality of 6.3 per 1000 live births. Forty-two of these (3.5 per 1000 live births) had a lethal congenital malformation.
Tables IV-VI summarize the details of 221 infants with I.R.D.S. born at Oxford and weighing more than $1000 \mathrm{~g}$. Severe illness, as judged by a large $\mathrm{A}-\mathrm{aDo}_{2}$ or the need for I.P.P.V. or C.D.P. before the hyperoxia test could be carried out, was commoner in infants of low birth weight. The overall mortality was $9.5 \%$ (see table VI). The fall in mortality from $28.6 \%$ in infants with an $\mathrm{A}-\mathrm{aDo}_{2}$ of more than $76.4 \mathrm{kPa}(575 \mathrm{~mm} \mathrm{Hg})$ to $2.0 \%$ in infants with an $\mathrm{A}-\mathrm{aDo}_{2}$ of less than $56.5 \mathrm{kPa}(425 \mathrm{~mm} \mathrm{Hg})$ was significant $\left(\chi^{2}=11.89\right.$; D.F. $=1$; $\mathrm{P}<0.001$ ). The mean birth weight of the infants with an $\mathrm{A}-\mathrm{aDo} \mathrm{O}_{2}$ of over $76.4 \mathrm{kPa}$, however, was significantly lower than that of the other infants in whom hyperoxia tests were carried out (table IV).

The mortality rate in the 200 infants breathing spontaneously by 15 minutes after birth was $4.5 \%$ (table V). (Many of these infants had required a short period of I.P.P.V. for apnoea at birth before starting to breathe.) Twenty-one infants who developed I.R.D.S. required I.P.P.V. from the moment of birth and never established spontaneous respiration. Their mortality rate was $57 \%$ (table VI). This difference is highly significant $\left(\chi^{2}=37.37 ; P<0.001\right)$. In the last 15 months of the study 113 infants with I.R.D.S. established spontaneous ventilation. Of these, 19 required C.D.P. and 16 I.P.P.V. subsequently; all survived. During this period seven infants died from H.M.D.; all were severely asphyxiated and were in the group needing I.P.P.V. from birth.

Infants with a poorer hyperoxia test result required ventilatory assistance (C.D.P. or I.P.P.V.) more frequently. The trend from $85.7 \%$ requiring assistance when the $\mathrm{A}-\mathrm{aDo}_{2}$ exceeded $76.4 \mathrm{kPa}$ to $26.2 \%$ in infants with an $\mathrm{A}-\mathrm{aDo}_{2}$ of under $56.5 \mathrm{kPa}$ is significant $\left(\chi^{2}=19.59\right.$; D.F. $\left.=1 ; \mathrm{P}<0.001\right)$.

Of the 200 infants who established spontaneous respiration 56 received ventilatory support. Twenty-nine required C.D.P. only; one of these infants collapsed and died at 8 days of age with an Escherichia coli septicaemia but the other 28 survived. Twenty-seven required I.P.P.V.; the time at which this was started is shown in table VII.

During the period of study 20 infants with I.R.D.S. were admitted from outside units (table VIII). None had been ventilated from birth The death rate of $15 \%$ was just significantly higher $\left(x^{2}=3.886\right.$; $P=0.05)$ than that of the 200 infants born in Oxford who breathed spontaneously for some time after birth.

Twenty-four infants with a birth weight of under $1000 \mathrm{~g}$ were admitted to the unit. In 14 of these, active attempts were made at resuscitation, including long-term I.P.P.V. All the infants fulfilled the clinical criteria for I.R.D.S. Three survived after periods of I.P.P.V., though this was not required from the time of birth. All but two of the 11 who died were found at necropsy to have H.M.D., the

TABLE IV-Mortality in Infants on whom Hyperoxia Test was Carried Out

\begin{tabular}{|c|c|c|c|c|c|c|c|}
\hline \multirow{2}{*}{ Group* } & \multirow{2}{*}{$\begin{array}{c}\text { Mean Birth Weight (g) } \\
\pm \text { S.E. of Mean }\end{array}$} & \multirow{2}{*}{$\begin{array}{l}\text { No. of } \\
\text { Infants }\end{array}$} & \multicolumn{3}{|c|}{ No. Requiring Ventilatory Assistance } & \multicolumn{2}{|c|}{ Deaths } \\
\hline & & & C.D.P. & I.P.P.V. & $\%$ & No. & $\%$ \\
\hline $\begin{array}{l}1 \\
2 \\
3 \\
4 \\
5\end{array}$ & $\begin{array}{l}1597 \pm 161 \\
2073 \pm 175 \\
2478 \pm 211 \\
2165 \pm 165 \\
2350 \pm 87\end{array}$ & $\begin{array}{r}7 \\
6 \\
13 \\
17 \\
103\end{array}$ & $\begin{array}{r}3 \\
3 \\
2 \\
2 \\
15\end{array}$ & $\begin{array}{r}3 \\
2 \\
3 \\
4 \\
12\end{array}$ & $\begin{array}{l}85 \cdot 7 \\
83 \cdot 3 \\
38 \cdot 5 \\
35 \cdot 3 \\
26 \cdot 2\end{array}$ & $\begin{array}{l}2 \\
1 \\
1 \\
2 \\
2\end{array}$ & $\begin{array}{r}28 \cdot 6 \\
16 \cdot 7 \\
7 \cdot 7 \\
11 \cdot 8 \\
2.0\end{array}$ \\
\hline Total & $2292 \pm 54$ & 146 & 25 & 24 & $33 \cdot 6$ & 8 & $5 \cdot 5$ \\
\hline
\end{tabular}

For increasing mortality with poor hyperoxia test result: $\chi^{2}=11.89 ;$ D.F. $=1 ; P<0.001$.
See table II.

TABLE V-All Infants who Established Spontaneous Respiration

\begin{tabular}{|c|c|c|c|c|c|c|c|}
\hline \multirow{2}{*}{ Category of Infant } & \multirow{2}{*}{$\begin{array}{c}\text { Mean Birth Weight (g) } \\
\pm \text { S.E. of Mean }\end{array}$} & \multirow{2}{*}{$\begin{array}{l}\text { No. of } \\
\text { Infants }\end{array}$} & \multicolumn{3}{|c|}{ No. Requiring Ventilatory Assistance } & \multicolumn{2}{|c|}{ Deaths } \\
\hline & & & C.D.P. & I.P.P.V. & $\%$ & No. & $\%$ \\
\hline $\begin{array}{l}\text { Hyperoxia test infants } \\
\text { Infants with no hyperoxia test data } \\
\text { C.D.P. from admission }\end{array}$ & $\begin{array}{l}2292 \pm 54 \\
2607 \pm 78 \\
1438 \pm 143\end{array}$ & $\begin{array}{r}146 \\
48 \\
6\end{array}$ & $\begin{array}{r}25 \\
4\end{array}$ & $\begin{array}{r}24 \\
1 \\
2\end{array}$ & $\begin{array}{r}33 \cdot 6 \\
2 \cdot 1 \\
100 \cdot 0\end{array}$ & $\begin{array}{l}8 \\
1\end{array}$ & $\begin{array}{r}5 \cdot 5 \\
16 \cdot 7\end{array}$ \\
\hline Total & $2341 \pm 46$ & 200 & 29 & 27 & $28 \cdot 0$ & 9 & 4.5 \\
\hline
\end{tabular}

TABLE VI-Comparison between Infants who Established Spontaneous Respiration and Those who Did Not

\begin{tabular}{|c|c|c|c|c|c|c|c|}
\hline \multirow{2}{*}{ Category of Infant } & \multirow{2}{*}{$\begin{array}{l}\text { Mean Birth Weight (g) } \\
\pm \text { S.E. of Mean }\end{array}$} & \multirow{2}{*}{$\begin{array}{l}\text { No. of } \\
\text { Infants }\end{array}$} & \multicolumn{3}{|c|}{ No. Requiring Ventilatory Assistance } & \multicolumn{2}{|c|}{ Deaths } \\
\hline & & & C.D.P. & I.P.P.V. & $\%$ & No. & $\%$ \\
\hline $\begin{array}{l}\text { Infants breathing spontaneously } \\
\text { I.P.P.V. from birth }\end{array}$ & $\begin{array}{l}2341 \pm 46 \\
1549 \pm 117\end{array}$ & $\begin{array}{r}200 \\
21\end{array}$ & 29 & $\begin{array}{l}27 \\
21\end{array}$ & $\begin{array}{r}28 \cdot 0 \\
100 \cdot 0\end{array}$ & $\begin{array}{r}9 \\
12\end{array}$ & $\begin{array}{r}4 \cdot 5 \\
57 \cdot 1\end{array}$ \\
\hline Total & $2266 \pm 46$ & 221 & 29 & 48 & $34 \cdot 8$ & 21 & $9 \cdot 5$ \\
\hline
\end{tabular}

For higher mortality in infants ventilated from birth: $\chi^{2}=55.28 ;$ D.F. $=1 ; P<0.001$. 
TABLE VII-Time of Starting I.P.P.V. in Infants Previously Breathing Regularly

\begin{tabular}{l|c|c|c|c|c|c}
\hline \multicolumn{1}{c|}{ Age (hours): } & $2-$ & $12-$ & 24 & $48-$ & $\geqslant 72$ & Total \\
\hline $\begin{array}{l}\text { No. starting I.P.P.V. } \\
\text { No. of deaths }\end{array}$ & 9 & 4 & 6 & 5 & 3 & 27 \\
\end{tabular}

TABLE VIII-Infants with I.R.D.S. Referred from Outside Units

\begin{tabular}{l|c|c|c}
\hline & $\begin{array}{c}\text { No. of } \\
\text { Infants }\end{array}$ & $\begin{array}{c}\text { No. Requiring } \\
\text { C.D.P./I.P.P.V. }\end{array}$ & $\begin{array}{c}\text { No. of } \\
\text { Deaths }\end{array}$ \\
\hline Hyperoxia test $<12$ hours & 3 & 2 & 1 \\
Assessed $>12$ hours & 7 & & \\
No gas measurements available & 2 & 1 & 2 \\
C.D.P. on admission (3-13 hours) & 5 & 5 & 3 \\
\hline \multicolumn{1}{c|}{ Total } & 20 & 8 & 2 . on admission (3-35 hours) \\
\hline
\end{tabular}

two exceptions having a massive pulmonary haemorrhage and an intraventricular haemorrhage, respectively.

\section{Discussion}

The mean age at which the hyperoxia test was carried out was not stated either by Boston et al. ${ }^{2}$ nor by $\mathrm{us}^{3}$; in this series, however, it was usually under 3 hours (table I). Though the test may provide some guide to the severity of I.R.D.S., particularly if serial testing is carried out or if carried out later than 3 hours, in this study it had little prognostic value for mortality. It may, however, have some value in predicting a group of infants in whom C.D.P. should be started sooner rather than later. The data in table IV suggest that any infant with an $\mathrm{A}-\mathrm{aDo}_{2}$ of over $69.8 \mathrm{kPa}(525 \mathrm{~mm} \mathrm{Hg})$ should be started on C.D.P. as soon as possible.

In this series only 21 infants of over $1000 \mathrm{~g}$ at birth who were born in the hospital died of H.M.D. in a 33-month period. Despite this it was possible to identify one major adverse prognostic factor. The need for assisted ventilation from birth carried a mortality rate of $57 \%$, compared with a rate of only $4.5 \%$ in infants with I.R.D.S. breathing spontaneously and adequately within 15 minutes of delivery (table VI). In the last 15 months of the study the discriminant value was even greater, since the mortality rate in infants breathing spontaneously was zero. Out of 113 cases of I.R.D.S. admitted to the unit during this time the seven deaths were in infants having I.P.P.V. or C.D.P. from birth.

Whenever a low mortality rate is reported in a series of infants with I.R.D.S. there is always a suspicion that many cases might have been mild or would have been included by other workers under the heading of one of the I.R.D.S. variants attributed to delayed clearing of pulmonary fluid. Though cases of known aspiration were excluded from our series, 69 infants were of more than 37 weeks of gestation and 86 weighed more than $2500 \mathrm{~g}$; however, 12 of the former and 15 of the latter needed either I.P.P.V. or C.D.P. None of the heavier infants died. We cannot distinguish-clinically or radiologically-respiratory distress in these larger and more mature infants from that in the small, preterm baby, which is invariably diagnosed as H.M.D. The main point, however, is that with the prognostic evaluation suggested it does not matter how many mild cases of I.R.D.S. are included, since almost all of those in the good prognostic group should survive. Furthermore, the increased mortality with lower birth weight and gestational age does not provide such a clear distinction between good and bad prognostic groups as does the need for I.P.P.V. from birth (table IX).

Though the mortality was low in the 200 infants with I.R.D.S. capable of establishing adequate respiration, there can be no doubt that many had severe disease. Twentyseven of them required a period of I.P.P.V. and a further 29 a period of C.D.P. on the basis of a $\mathrm{PaO}_{2}$ of less than $8 \mathrm{kPa}$ $(60 \mathrm{~mm} \mathrm{Hg})$ in an $\mathrm{F}_{1} \mathrm{O}_{2}$ of 0.6 . The indications for starting I.P.P.V. are shown in table III. In four of the eight deaths there was a complicating factor. Three infants had pneumothoraces and one had a haemophilus septicaemia acquired from the mother during delivery. In the absence of such complications, therefore, most infants in the good prognostic group survived, even if they had required a period of I.P.P.V., and in the last 15 months of the study all 16 such infants lived.

Infants transferred from outside hospitals had a higher mortality than those born in our hospital. Though the numbers are small and they were a selected group they can still be assessed on the basis of their ability to establish adequate ventilation from birth, as suggested above. Since all were referred from units where survival for any length of time was possible only if they were breathing spontaneously, they were a group of infants all of whom should have survived had they been born in a hospital providing neonatal intensive care.

It is impossible to say which of the advances in treatment is responsible for the improved survival rate but the implications of the results are clear. Firstly, the hyperoxia test is of little value for assessing the prognosis for infants with I.R.D.S., particularly if the test is carried out in the first hour or two of life. It may, however, be of value in delineating a group of infants in whom C.D.P. should be instituted soon after delivery. Secondly, infants who require I.P.P.V. from the moment of birth have a bad prognosis. This not only provides a method for comparing results when infants are referred from outside centres but also identifies immediately after birth those infants needing the full services of an experienced neonatal intensive care unit. The 12 infants who died after being on I.P.P.V. from birth had an average Apgar score of 1.8 at one minute and a mean $\mathrm{pH}$ of 7.05 at one hour. A decreased mortality for this group of infants will be achieved only by a high standard of perinatal care in an attempt to minimize the duration and severity of intrapartum asphyxia. Generally, however, the mortality from I.R.D.S. of infants whose birth weight is $1000 \mathrm{~g}$ or more should be less than $5 \%$. Similar figures have been reported by Dunn, ${ }^{10}$ and these results provide us with what should now be regarded as the highest acceptable mortality rates for infants with I.R.D.S.

\begin{tabular}{|c|c|c|c|c|c|}
\hline & \multirow{3}{*}{$\begin{array}{l}\text { No. of Cases } \\
\text { of I.R.D.S. }\end{array}$} & \multicolumn{4}{|c|}{ No. of Deaths } \\
\hline & & \multirow{2}{*}{ Bad Prognosis } & \multirow{2}{*}{ Good Prognosis } & \multicolumn{2}{|c|}{ Total } \\
\hline & & & & No. & $\%$ \\
\hline Gestation $\left\{\begin{array}{l}28-30 \\
31-33 \\
34-36 \\
\text { (Weeks) }\end{array}\right.$ & $\begin{array}{l}29 \\
43 \\
77 \\
69\end{array}$ & $\begin{array}{l}7 \\
3 \\
2\end{array}$ & $\begin{array}{l}4 \\
2 \\
3\end{array}$ & $\begin{array}{r}11 \\
5 \\
5\end{array}$ & $\begin{array}{r}37.9 \\
11.6 \\
6.5\end{array}$ \\
\hline Total & $218^{*}$ & 12 & 9 & 21 & $9 \cdot 6$ \\
\hline Birth Weight $\left\{\begin{array}{c}1001-1500 \\
1501-2000 \\
2001-2500 \\
>2500\end{array}\right.$ & $\begin{array}{l}41 \\
35 \\
59 \\
86\end{array}$ & $\begin{array}{l}8 \\
4\end{array}$ & $\begin{array}{l}5 \\
2 \\
2\end{array}$ & $\begin{array}{r}13 \\
6 \\
2\end{array}$ & $\begin{array}{r}31.7 \\
17.1 \\
3.4\end{array}$ \\
\hline Total & 221 & 12 & 9 & 21 & $9 \cdot 5$ \\
\hline
\end{tabular}

*Three infants (survivors) were born at 27 weeks of gestation. 
We should like to thank Miss P. Townshend, the sisters and nursing staff of the S.C.B.U. at the John Radcliffe Hospital, and the many excellent registrars and residents on the unit without whose scrupulous care these results would not have been possible. The infants in this study were under the care of J.P.M.T. and Drs. H. L. Ellis, B. D. Bower, and D. Pickering.

\section{References}

${ }^{1}$ Davies, P. A., et al., Medical Care of Newborn Babies, Spastics International Medical Publications, No. 46, p. 116. London, Heinemann, 1972.
${ }^{2}$ Boston, R. W., Geller, F., and Smith, C. A., Fournal of Pediatrics, 1966, $68,74$.

${ }^{3}$ Roberton, N. R. C., et al., Lancet, 1968, 1, 1323.

4 Gregory, G. A., et al., New England fournal of Medicine, 1971, 284, 1333.

${ }^{5}$ Fanaroff, A. A., et al., Fournal of Pediatrics, 1973, 86, 921.

${ }^{6}$ Kattwinkel, J., et al., Pediatrics, 1973, 52, 131.

7 Baum, J. D., and Roberton, N. R. C., Archives of Disease in Childhood, 1974, 49, 771 .

8 Roberton, N. R. C., "Respiratory Disease in Infancy and the Newborn," in Recent Advances in Respiratory Disease, ed. T. H. Stretton. London, Churchill, 1975.

9 Blake, A. M., et al., Lancet, 1973, 1, 1176.

10 Dunn, P. M., Proceedings of the Royal Society of Medicine, 1974, 67, 248.

\title{
An Abnormality of Oestrogen Feedback in Amenorrhoea- Galactorrhoea
}

\author{
M. R. GLASS， R. W. SHAW，W. R. BUTT， R. LOGAN EDWARDS， D. R. LONDON
}

British Medical fournal, 1975, 3, 274-275

\section{Summary}

Fourteen patients with amenorrhoea and hyperprolactinaemia but no evidence of pituitary tumours were each given an intramuscular injection of $1 \mathrm{mg}$ oestradiol benzoate. Thirteen patients failed to release luteinizing hormone in response to the oestrogen. This hypothalamic abnormality may help to explain the menstrual disturbances in subjects with hyperprolactinaemia.

\section{Introduction}

The many physiological and pathological conditions in which serum prolactin levels are consistently raised are usually associated in women with amenorrhoea. Prolactin is increased when hypothalamic control of the pituitary is lost, presumably because of a lowered secretion of prolactin-inhibiting factor. ${ }^{1}$ Recently it has been shown in vitro that raised prolactin levels may inhibit ovarian steroid biosynthesis. ${ }^{2}$ It has therefore been suggested that in-vivo steroid feedback to the hypothalamicpituitary unit is reduced, with subsequent amenorrhoea. ${ }^{3}$ Prolactin could also conceivably inhibit directly pituitary release of gonadotrophins, though there is no evidence to substantiate this.

Much evidence indicates that exogenously administered oestrogens can produce both negative and positive feedback effects on gonadotrophin release in regularly menstruating women. ${ }^{4-7}$ If reduced steroid feedback is the correct explanation for the anovulation in hyperprolactinaemia the administration of exogenous oestrogens should produce a normal release of gonadotrophins. We tested this by giving oestradiol benzoate to women with amenorrhoea and galactorrhoea associated with hyperprolactinaemia and measuring the changes produced in serum luteinizing hormone (LH) and follicle-stimulating hormone (FSH).

\footnotetext{
Department of Clinical Endocrinology, Birmingham and Midland Hospital for Women, Birmingham B11 4HL

M. R. GLASS, M.B., M.R.C.o.G., Research Registrar

R. W. SHAW, M.B., CH.B., Research Registrar

W. R. BUTT, D.SC., F.R.I.C., Consultant Biochemist

R. LOGAN EDWARDS, F.R.C.S., F.R.C.O.G., Consultant Gynaecologist

Queen Elizabeth Hospital, Birmingham B15 2TH

D. R. LONDON, D.M., F.R.C.P., Consultant Physician
}

\begin{abstract}
Methods
Patients.-Fourteen patients with consistently raised serum prolactin levels and amenorrhoea of more than 12 months' duration were investigated. Five presented with accompanying galactorrhoea, galactorrhoea was first noted on examination of the breasts in eight, and in the remaining patient only clear serous fluid could be expressed from the breasts. Patients with radiologically apparent pituitary tumours were excluded from this study.

Test Procedure.-Oestradiol benzoate B.P. $1 \mathrm{mg}$ was given intramuscularly and venous blood samples taken at 0 hours and after 24, 48, 56, 72, and 96 hours. Serum oestradiol and progesterone were estimated at 0 hours to exclude recent ovulation and LH and FSH were measured in all samples. A positive response was defined as an increase in LH of $8 \mathrm{U} / 1$ and in FSH of $3 \mathrm{U} / 1$ above mean baseline values within 96 hours. ${ }^{8}$ The gonadotrophin release in response to LH-RH was assessed in all patients after injection of $100 \mu \mathrm{g} \mathrm{LH}-\mathrm{RH}$ (Hoechst Pharmaceuticals) as previously described. ${ }^{9}$

Hormone Measurements. - Serum LH, FSH, oestradiol, and progesterone were estimated using specific radioimmunoassays (R.I.A.). ${ }^{\ominus}$ Serum prolactin was measured by a double antibody R.I.A. using a modification of Sinha et al.'s method. ${ }^{10}$ The prolactin preparation HPr V-L-S No. 1, supplied by the National Institute of Arthritis and Metabolic Diseases, U.S.A., was used as standard and label. Iodination was by the method of Redshaw and Lynch ${ }^{11}$ using sodium hypochlorite $1 \mathrm{mmol} / \mathrm{l}$ as an oxidant. The product was passed through Sephadex (Pharmacia Fine Chemicals, Sweden) G25 and G100 columns before use to remove free iodide and polymerized material. Prolactin antibody was supplied by Dr. A. S. McNeilly. ${ }^{12} 13$ Donkey anti-rabbit serum (Burroughs Wellcome) was used for final separation. The normal values of 30 regularly menstruating women ranged from 6-32 $\mu \mathrm{g} / 1$ (Mean \pm S.D., $=12.6 \pm 6.0 \mu \mathrm{g} / \mathrm{l}$ ) and were similar to those reported by McNeilly. ${ }^{12}$
\end{abstract}

\section{Results}

Basal serum prolactin, oestradiol, and gonadotrophin estimations and LH-RH responses of the patients are summarized in the table. Prolactin was clearly raised above the upper limit of normal in all patients. Basal oestradiol and gonadotrophins were within the normal range (mean \pm 2 S.D.) for the early follicular phase. ${ }^{\circ} \mathrm{LH}$ and FSH release after LH-RH were either normal or exaggerated when compared with the responses of normal women in the early follicular phase. ${ }^{\circ}$

After administration of the oestradiol benzoate circulating levels of FSH, and LH in most cases, were initially suppressed in all patients. Only one patient (case 14) responded normally as defined by an increase in LH 72 hours after the oestradiol benzoate (see fig.). The remaining 13 failed to release gonadotrophin (see fig., case 11). 